\title{
Original Article \\ Design control in post-reform China: A case study of Shenzhen's commercial office development
}

\author{
Zhaohua Deng
}

School of City and Regional Planning, Cardiff University, Glamorgan Building, King Edward VII Avenue, Cardiff CF10 3WA, UK.

E-mail: dengz2@cardiff.ac.uk

\begin{abstract}
This paper explores current trends in design review in China, in order to understand its objectives and achievements, and to see how the political and economic conditions of a city affect both the control process and the design outcome. It locates the current practice of design control within an international context by briefly reviewing the Western design-control literature, reviewing Chinese urban form in the pre-reform period, and then focusing on one detailed case study of development control, that of a recent commercial office development in the city of Shenzhen, which is something of a leader in the field of design review in China. This paper concludes that the current good practice in design control in China requires political support for intervention, additional design skills within the planning function and a moving away from elevational control to address the quality of public space, giving statutory status to the Statutory Map, and creating a mechanism to regularize planning negotiation. Meanwhile, sustainable design and construction issues remain outside of the development control agenda, while public participation levels are still low and the planning appeal mechanism needs to be improved. The introduction of a sophisticated design-control practice is dependent on another level of institutional reform.
\end{abstract}

URBAN DESIGN International (2009) 14, 118-136. doi:10.1057/udi.2009.13

Keywords: urban design control; post-reform China; commercial office; Shenzhen

\section{Introduction}

During the market reform in China, urban design was strongly promoted by the local government as a place-promotion strategy (Wu et al, 2007) and by the developers as their image-building tool. This is a narrow understanding of urban design focusing only on its visual and aesthetic aspects and the nature of the architectural object (as an icon). Fortunately, development control practice in some coastal cities is evolving from elevational control towards a more substantive concern for urban environmental quality. How this is being done is worth exploring, to discover what might constitute best practice to guide future development in rapidly growing Chinese cities.

There is little evidence showing how the urban planning institution affects the newly introduced urban design practice in China. The Western world has developed substantial literature on design-control practice (Sheer and Preiser, 1994;
Loukaitou-Sideris and Banerjee, 1998; Nelissen, 1999; Schaller, 1999; Punter, 1999a, 2003), which shows how different countries share a common ground when practicing urban design control. Emerging together with the Chinese marketization, development control is also a new activity in China. Finding the best practice in the Chinese context while incorporating Western lessons would seem to be valuable for Chinese cities. This research aims to fill this gap and provide a positive example of the practice of design control in a fast-developing city. It investigates the processes and instruments being used by planners and the impacts of the Chinese planning system on design-control practice. It also examines to what extent the local economic and political factors influence design outcomes. Indepth case studies are capable of generating an understanding of institutional activities and decision-making (Yin, 2003). Limited by the space, this paper adopts an in-depth single-case study 
approach. The case study chosen is located in Shenzhen, the leading Special Economic Zone in China, the experiences of which are often experimental, providing solid examples of innovations for national policy-making, such as privatising public land and its planning management innovations. The case study includes site investigation, searching the relevant urban planning documents and meeting minutes, interviewing the planning officers, and participant observation in the process.

\section{Controlling Development by Design}

The Anglo-American experience provides fruitful lessons on design control, including their experience in developing urban design as public policy and lessons on developing good practice in design review. Contrasting their experiences with that of China would be a valuable comparison for those who seek better practice. The following briefly reviews the evolution of developing urban design as public policy in the United Kingdom and the United States, with the emphasis on how the urban design objectives change over time and how urban design is attached to the relevant planning system. It also discusses some of the good practices in design review, which reflect how urban design control could be better carried out from the Western point of view.

The evolution of urban design as public policy in Britain is a story about the central government's evolving understanding of design, its growing recognition of the value of urban design and its growing confidence in controlling development by design. The 1947 Town and Country Planning Act marked the start of the post-war British planning system that is still shaping town planning practice today, in which public design intervention in private development is legitimated based on the local 'discretionary power' on all kinds of 'material considerations' (Cullingworth and Nadin, 2006). The British central government has been using planning guidance and circulars to direct the local planning decision-making, including the decisions on design matters. Until the 1950s, the central government's conceptions of design still remained 'matters of taste and ... individual opinion', making the local governments lose confidence in design intervention (see Punter, 1987). In the 1950s and 1960s, the conservation movement opened a new chapter for British design control, in which the scholars criticised the 'scientific' and 'modernist' approach to design, and initiated the townscape movement. Having the same effect as Lynch's study in the USA (1960), Cullen's Townscape study (1961) was applied by many local authorities to develop their design guidance in 1970s. In the 1980s, people such as the Prince of Wales and Bentley et al, (1985) started to synthesise some generic urban design ideas that later were applied to some city-centre urban design studies, such as that of Birmingham (see Wright, 1999). The 1990s marked a shift from an appeal-led laissez-faire development climate towards a more environmentally responsible planning system in the United Kingdom (Punter, 1999c). The Secretary of State for the Environment from 1993 took a holistic view of design, broadening it with an environmental agenda. The Department of the Environment for the Conservatives sought to promote quality and responsibility in planning through the 1994 'Quality in Town and Country' initiative, which identified the crucial issues in urban design such as mixed use, density, transportation, design guidelines, design training and so on. Urban design has been very much on the agenda of New Labour since 1997. The Urban Task Force was established in 1998 by the Deputy Prime Minister to resolve urban decline, and it broadened the government's vision with the idea of design-led regeneration to achieve social well-being and environmental responsibility and an urban renaissance (UTF, 1999). To facilitate the designled regeneration, the Central Government publishes various planning guidance materials and design guides, including the long-awaited governmental design manual By Design (DETR and CABE, 2000). To tackle the longstanding problem of highway engineers designing the city with a lack of design training, Manual for Streets (DfT et al, 2007) was published to promote lightly trafficked residential streets. As sustainability is climbing up the political agenda, environment-friendly urban design has also begun to be promoted.

The evolution of developing urban design as public policy in the United States and Britain has been similar, but the history of this evolution has been different. The Columbian EXPO in Chicago in 1893 encouraged the local elites to trace the European tradition of city design, with a belief that grand design can increase social responsibility and can result in a more harmonised social order, and subsequently led to the 
City Beautiful movement. But the City Beautiful movement had little impact on urban planning save for its influence on Civic Centres and government buildings, and far more influential was the New York Zoning Ordinance introduced in 1916 to prescribe exclusive land use and build form control (Loukaitou-Sideris and Banerjee, 1998). The objective of this first Zoning Ordinance was to protect and enhance property value by giving faith to scientific rationality and efficiency in the planning of urban form, but was criticised for a lack of any planning component to address the social life in the city (Cullingworth and Roger, 2003). After the Great Depression in the late 1930s, American cities started to redevelop their downtowns to compete with the suburbs by producing massive masterplans from the 1950s, which signalled urban design entering an infant stage of public policy and promoting private investment. In the 1960s and the 1970s, some seven hundred Central Business District (CBD) plans emerged and committed to modern and efficient business centres with comprehensive and totalised modes to provide efficient and functional urban form. Suburban shopping malls came to the centres, with freeway loops on the outskirts and pedestrians dominant inside (Loukaitou-Sideris and Banerjee, 1998). At the same time, the notions of advocacy, pluralism, participatory planning and design were promoted by people such as Jane Jacobs and Kevin Lynch. Jacobs (1961) criticises the brutal town centre redevelopments, and promotes the values of traditional and permeable neighbourhood, mixed-use and highdensity urban life, short city blocks with active frontages, and gradual investments. Lynch (1960) abandons the previous top-down approach to planning and design, and goes down to the street to research and conceptualize people's perceptions on urban environment before the design. His research defined some large public purposes and aims in the built environment, by regulating private development within the guidelines. In New York in the 1960s and 1970s and in other American cities in the 1970s and 1980s, urban design as public policy came to its mature stage. Jacob and Lynch's approaches to urbanism were slowly penetrating the urban design practice. New York in the 1960s took another pioneer role in urban design. Supported by Mayor John Lindsey, URBAN DESIGN Group for New York was created in 1967. Urban design as public policy, with the 1961 reform of New York's Zoning Ordinance, took the forms of design review, incentive zoning legislation, special design districts, landmark preservation, rebuilding theatre districts and shopping streets, neighbourhood planning and others, to safeguard the city's interests in private development instead of the brutal large-scale public urban renewal (Barnett, 1974). In the mid-1970s, New York adopted both design guidelines to spell out some detailed requirements on the open space and a permitting process with a negotiation character. Until 1982, the bonuses were radically reduced except for plazas and urban parks. Amenities provided as a way to ask for bonuses were now mandatory. In the 1970s and 1980s, urban design plans and Zoning Ordinances were treated as the base for development control negotiation around the American downtowns (Loukaitou-Sideris and Banerjee, 1998). After the 1990s, originating from suburban development, the New Urbanism idea of mixed-use, transit-oriented, local character and permeability slowly penetrated city-centre redevelopment, and repaired the urban fabric (Katz, 1994). At the same time, urban design guidance was developed as a common tool to guide the land development in American cities (Punter, 1999b).

Based on the above description, some conclusions can be drawn. First, the practice of urban design is embedded within the given distinct mechanism of an individual country, largely depending on how the planning system is shaped. The British central government has a strong interest in local planning decision-making, by using central guidance and appeal mechanisms to influence local discretion (see Punter, 1987). Therefore, the central government's conception of design issues has long influenced the local authorities' ability concerning design control. While the American governments at Federal and State levels have little interest in local planning issues, the American local governments tend to adopt various approaches on regulating land development, but mainly using zoning by-laws (see Cullingworth and Roger, 2003). Therefore, adapting the zoning regulation has been the major approach for American cities to implement design control. Second, the United States and Britain share some common views on defining urban design. In the first half of the twentieth century, design in planning was largely regarded as an aesthetic issue, with strong emphasis on building external appearance. Owing to the failure of the 'scientific' and 'efficient' approach to planning and design, the 
value of traditional neighbourhood was promoted again. In the second half of the last century, urban design was slowly taking the social and environmental approaches to promote mixed-use, vitality, liveability and, recently, sustainability. These urban design principles are well researched and universally applicable. Learning from the AngloAmerican lessons, one country can adopt these principles according to its local circumstances if it wants to construct a human and harmonized built environment. Third, given the differences in the nature of these two planning systems, British and American cities have been taking different approaches to addressing the urban design issues. The British central government has been providing central guides on design issues, including the conception of urban design, how design policy is written in local planning documents, how planning decision is made with regard to design issues and even how applicants can improve their design. The American cities have taken different approaches, mainly by amending their originally rigid zoning mechanism, by introducing flexible and incentive zoning, and also by introducing design guidance and negotiation to tackle the zoning rigidity. Currently, urban design is playing a crucial role in society, within which the quality of public space is significant. Different countries need to find their own ways to deal with the strength and the weakness of their own system, to realize their ideal urbanism.

Good practice on delivering high quality of urban environment has been an ongoing research project in the past decades, in which the search for a sophisticated process for better design outcome is one of the key issues. The literature identifies four main areas to improve the control practice based on the Anglo-American experience, which arguably can be used to evaluate the effectiveness and efficiency of a design-control mechanism elsewhere. These include the stage of design visioning, the tools to promote good design, the application of the generic design principles and the due process of control and review (Punter, 2007). The first area involves how a design vision is developed. It emerges from the legal challenges to the American design review practice, which indicates that aesthetic concern alone cannot initiate the use of the 'police power' to regulate the private development, unless the vision of urban design is committed to the community (Lai, 1988). It has also been proven as an opportunity, in which developing and monitoring a highquality environment vision with community and development industry supports is the safeguard to shape a high-quality built environment. Vancouver's waterfront mega-project development process is one of the exemplars (see Punter, 2003). Of course, in some fast-developing countries such as China, where the public involvement mechanism is to be developed, the political commitment to environmental quality will be the strongest support for the design vision. The second involves using a broad range of tools to promote good design. Potentially, each locality can find some incentive tools to promote good design, according to its local circumstances. Good practice internationally shows that planning negotiation based on urban design guidance (Punter, 1999b), incentive zoning based on design guide (Barnett, 1974), tax incentive (Lai, 1988), the use of landownership power (DCLG, 2006) and so on are all the available tools to promote good design. For example, American cities use urban design guidance and design review to crack the rigid zoning control mechanism and introduce negotiation-based discretionary zoning (Loukaitou-Sideris and Banerjee, 1998); British local authorities start to take the advantage of landownership power to use design code for large residential developments (DCLG, 2006). Lai, (1988, pp. 431-432) recognizes that many promotion tools for good design are actually beyond the control of planning authority, such as compensable regulation, eminent domain, public subsidy and tax policy, which require an outside support, mainly from political aspects. The issue here is how a locality can identify and develop the possible ways to achieve its environmental objectives, including the use of zoning, planning mechanism and other tools available. The third covers how the generic design principles can be incorporated within the development and control process, without compromising the design innovation. As discussed above, urban design has been long treated as aesthetic control on visual appearance and the control of elevations. The practice since the 1970 s has slowly moved towards community, vitality, accessibility and sustainability aspects of environmental quality in American (see Southworth, 1989; Punter, 1999b) and British cities (Biddulph, 1999). As urban design is a kind of innovative activity with the involvement of public interest, the balance between mandatory regulation and the room for innovation has long been a controversial debate (Blaesser, 1994; Lai, 1994). Therefore, how generic design principles are applied and how design 
freedom is allowed to be expressed should be carefully considered. Last but not least, an efficient and transparent permitting process in design intervention should be achieved if a system of design control is to withstand the legal challenge. An a priori written rule to make orderly discretionary decisions and keep judgments consistent and non-arbitrary is crucial for legitimating design intervention (Scheer and Preiser, 1994). To conclude, there might not be an ideal model to create high-quality built environment, because it relates to the historical, cultural, social, political and economic status of every individual locality. But the four areas here are the basic indicators worth looking at for the search for better practice, and are to be used later in the Chinese case study to facilitate the discussion.

\section{Development Control in China}

Development control hardly existed before China's reform in 1978. In feudal China, the ancient Chinese urban form was influenced by the Confucian ideology ${ }^{1}$ of rigid hierarchy in administrative, family and social levels, as well as the Tao ideology ${ }^{2}$ of the relationship between the human being and nature (Whitehand and $\mathrm{Gu}$, 2006). The former ideology was broadly expressed in the layout of most of the imperial capitals, and the latter ideology was used in the site selection of new cities, and had more influences in the layout of southern Chinese cities. After the Opium War, at the beginning of the twentieth century, modern planning concepts introduced by the Western planners (Esherick, 2000) and the Western-trained Chinese specialists (Zhang, 2002) were seen in China. But due to (inter-) national conflicts and the burst of the Civil War, the implementation of modern planning concepts was limited, and development control activities hardly existed in this period. After liberation in 1949, taking the Soviet experts' suggestions, the Socialist Chinese leaders and planners considered urban planning as the realization of the nation's economic development programme. The urban design practice in this period therefore was to facilitate the short-term industrial development. Xie and Costa (1991) identify six characteristics of urban design activity in Socialist China: adopting the Soviet design ideas and architectural styles; industrial production first and then civil construction; seeking 'Socialist grandeur' in urban character; abandoning the 'capitalist design theories' in favour of traditional Chinese symmetrical and regular urban form; tall buildings only erected for Socialist projects; and standardization and equalization in housing provision and layout. In this period, urban form was driven by a few political and economic conditions such as resource scarcity (Lu, 2006), socialist ideology (Xie and Costa, 1991), heavy industry investment $(\mathrm{Yu}, 2004)$ and work-unit dominance (Xie and Costa, 1991; Lu, 2006; Wu et al, 2007). In this period, the pure central-plan planning system and the top-down resource allocation strategy did not require development control in the Western sense. The functions of the local planning authorities were diminished and limited only to the domain of providing necessary infrastructure for the national or local economic plans. The relatively resourceful work units were actually the major drivers that transformed the urban form, by bargaining with the upper level of administrative units and with the local governments. Although the above phenomenon no longer exists in post-reform China, the ancient Chinese ideal urban form and the socialist grandeur aesthetic still influence current practice.

As the market reforms, the political and market conditions have been transforming the Chinese urban form. It is fair to say that the contemporary urban planning, development control and urban design practice in China began in the 1980s. There are a few key characteristics of post-reform China's urban development. First, gradualist partial reform takes place instead of the 'radical marketization' in the former Soviet blocs (Logan, 2002). The Chinese state reforms the economic system but remains politically unchanged, privatizes urban land by a pay-to-use policy but retains partly government allocation, and decentralizes the decision-making power to the local level but retains strong central control of political appointments. This leads to the recent privatisation processes being accompanied by a complex system of property rights, which in Logan's view is a 'guise of socialism', including 'the use of land, the built environment, and future development, a set of social relations involving control, extraction of profit, and investment' (2002). From the reform, the local government gains the decisionmaking power, gains the income from selling urban land at a negotiated price, tries to attract inward investments, and is monitored by the upper tier of government largely in terms of the local economic performance. Bearing on its nature as a public body, the state has a new task to 
regulate private development in the interest of the public, but this function has been largely sacrificed in the partial reform process.

Second, developer-government coalitions are the main drivers changing urban form. Alongside the decentralization of the government power to local jurisdiction; the limited centrally allocated resources; the privatization of public land use right; and the commodification of real estate market, the Chinese local governments act as the market regulators and the players to promote progrowth urban development strategies (Wu et al, 2007). Speculative developments (office and housing) are promoted by local governments. Logan (2002) explains that this is because the local authorities control the land without sufficient funds to provide infrastructure, and therefore displace land development costs to public building companies or end users, and in turn, speculate on the value of prepared sites. Foreign direct investment (FDI) has contributed a large part of the speculative development since 1991 (Wu, 2000), and real estate soon accounted for more than a third of the value of new contracts signed for FDI (Logan, 2002). Subsequently, the FDI compensated the local government's rich-in-land and poor-in-cash situation and started to transform the cities dramatically. Zhengji Fu (2002) summarizes Shanghai's post-socialist development as having 'Chinese characteristics' such as implicit, informal (behind-the-scenes negotiation between local politicians and foreign capitals similar to the American-style growth machine politics) and project-based pro-growth coalition (such as new CBDs, new development districts, new industrial zones and large housing projects). $\mathrm{He}$ argues that this is because of China's asymmetrical reform - while the developmental aspect of the state has changed, the political aspect of the state remains intact.

Third, city marketing is treated as a new strategy to boost local economic development, and is deeply transforming the urban form. The tightened allocation of resources from central government and the decentralized power encourage the Chinese local states to seek every opportunity to capture the flowing capital. This further leads to intercity competition, 'city image building' and marketing campaigns. The urban form is modelled on New York's Manhattan, Paris' La Defense, London's Canary Wharf and others, which symbolize the economic flourish, particularly attracting the attention of the local politicians. International design competi- tions (urban design and architectural design) subsequently start to realize the local politicians' dreams in the Chinese cities. The design entries tend to wipe away the existing built form, adopt the traditional Chinese 'chessboard' street system, meet the 'grandeur' of the socialist aesthetic (straight and wide boulevards, large squares or grasslands) and create astonishing skyline to demonstrate China's new urban prestige. Chinese cities are becoming the Western cities criticized by Larice and Macdonald (2007) on the grounds that the distinct urban form is no longer pedestrian friendly, the functional aspects of the street are maximized by the increase of vehicle traffic, sacrificing the social aspects of the street'. As a result, the partial reform of the government function, the pro-growth urban development strategy and the image-building campaign all pay little attention to the daily life of the population within the urban environment, and potentially create barriers for a progressive development control practice.

The planning system was established in association with the market reforms. The 1989 City Planning Act (Standing Committee for the People's Congress P. R. C, 1989) delegated territorial power to municipalities in important functions of urban planning, ranging from planmaking to development control. The Act designated a two-tier urban plan system, namely Comprehensive Plan and Detailed Plan. The former is the only urban plan that has statutory status in the 1989 Act, and should be prepared according to the national and local economic plans. The Detailed Plan serves the function of transforming the principles and development parameters in the Comprehensive Plan to site or district levels. It carries the zoning parameters, and provides some basic guidance on development density, boundary and building height. Therefore, the plan-making process from the economic plan to the city Comprehensive Plan, and further to the Detailed Plan, is actually following the top-down ideology of the prereform era, which has shown its incapability in dealing with the bottom-up decision-making process in the real world. More significantly, economic planning takes a much larger role in decision-making and also has a bigger impact on the urban environment, minimizing the social improvement function of urban planning. In practice, instead of being a local piece of legislation like the Zoning Ordinance in the USA, the Detailed Plan is acting only as the technical 
guidance to facilitate the local government's land leasing. 'Two Permits and One Permission Note' is the core of the current Chinese development control mechanism introduced by the 1989 City Planning Act. According to the Act, if the proposed development is within the defined Urban Planning Area, the developer should obtain the 'Permission Note for Location', the 'Land Use Planning Permit' and the 'Building Construction Planning Permit' from the local planning department (Articles 30, 31, 32). During the application process, the developer and the planning officer in the Urban Planning Bureau are the two key players to negotiate and make decisions. Although there are other governmental departments or bureaus that take part in the process, they are only consulted, or provide relevant supplementary services. The lack of transparency is the main critique of the planning management process ( $\mathrm{Yu}, 2004 ; \mathrm{Wu}$ et al, 2007). The back-door decision-making process results in political will dominating the decision-making, and leads to governor corruption.

With a distinct publicly owned land policy and an established development control system, technically, urban design control can be easily applied in China. The only way to develop urban land in China is to buy the land usage right from the government. When selling the land for development, the government attaches some development conditions such as building density, land use, urban design considerations, public service requirements and so on. If the developer accepts the conditions, a Land Contract with these conditions is issued. If not, the land is not sold and no development takes place. Meanwhile, during the whole process, there are three main stages when the Urban Planning Bureau can intervene in the design of the proposed development: before the formal application takes place, the Bureau expresses its preferences; when issuing the 'Permission Note for Location', the Bureau draws the design requirements from the relevant Detailed Plan or URBAN DESIGN Plan, and based on the submitted initial site design plan formulates the planning and design conditions; and when issuing the 'Land Use Planning Permit', the 'Notes for Architectural Design', the Bureau expresses the detailed design requirements (Figure 1). At each of these stages, the developer can negotiate with the Planning Bureau in terms of the requirements. Therefore, the quality of built environment depends on the quality of plans or norms, as well as the skills of the planning officers within the Urban Planning Bureau. However, this is only the ideal situation where the local government is in a relatively strong position, when the development demand is relatively high and the local government has strong confidence in the city's economic performance. In locations where the local government has a strong will to attract investment, the local government may compromise and the developer may have more freedom to build what he or she wants. Facing the condition of a pro-growth urban development strategy, the ideal urban design-control model does not always reach its full potential.

We now turn our attention to a case study of a major office development in Shenzhen to illustrate the way that the system works currently.

\section{The Rise of Urban Design in Shenzhen}

Shenzhen is a city renowned for its innovation in local administration. It is an emerging Chinese city, with only 26 years of history, given birth at the same period as the China's market reform. For the past 26 years, as the leading experimental special economic zone, Shenzhen has been the test-bed for China's market economy, with strong support by the central government. It leads many new practices in land reform, urban development and urban governance. For example, it was the first city in China to apply the pay-to-use urban land policy in the early reform period, revealing that the valuable land resource could be used to facilitate the urban development (Zhu, 1999). This practice then later led to the change of the national land policy and the new land resource legislation. Shenzhen also produced the first local planning legislation to bring in a relatively transparent planning process. Currently, the city is restructuring its economy towards a servicebased one, and is aiming to be an international city' as well as a liveable one to attract more inward investment. To facilitate these aims, Shenzhen is taking progressive approaches to the practice of urban design. It is the first city in China to give a statutory status to urban design in local planning legislation.

Shenzhen has its own planning system regulated by local legislations, regulations and guidance. These are formed according to the national regulations and the local context. In Shenzhen, the most important local regulations such as Shenzhen Urban Planning Ordinance, Shenzhen Urban Planning Norm, Shenzhen Architecture and URBAN DESIGN Standard, Administration Handbook of the 


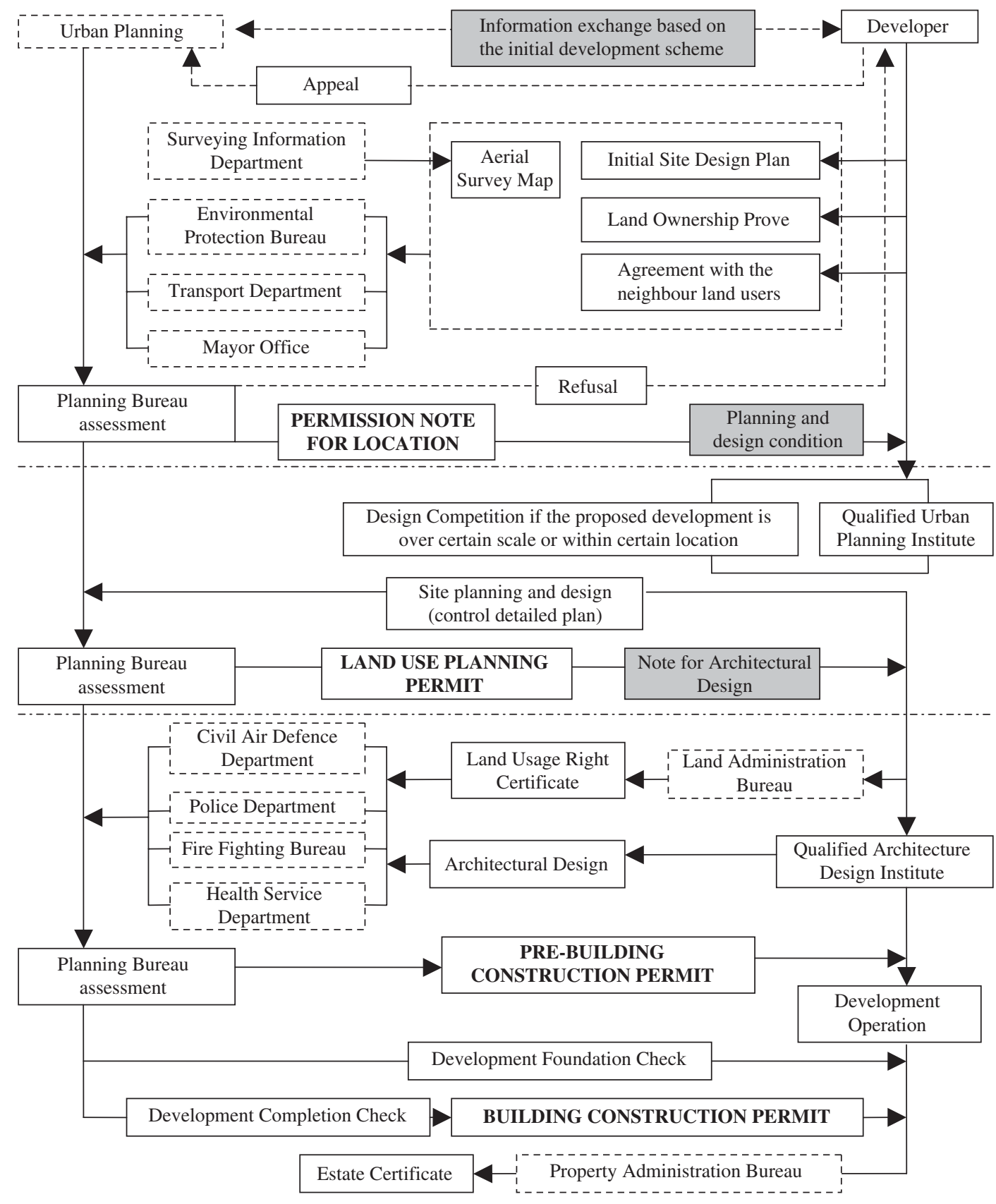

Figure 1: Urban planning management process in China.

Shenzhen Municipal Planning Bureau decide the planning system, technical requirements and even urban design practice. Shaped by these documents, Shenzhen's planning system has its own distinct characteristics. First, the Ordinance decides the establishment of the Shenzhen Urban Planning Board, which is responsible for the approval of urban plans. This practice enables the separation of the plan-making power from plan implementation of the Planning Bureau, which is considered a democratic governmental decision-making process. Second, it establishes Shenzhen's five-tier plan system, which includes a City Comprehensive Plan, Sub-regional Planning Strategy, a District Plan, Statutory Maps and Detailed Layout Plans. The contents and the level of details the plans should cover have been clearly defined in it. Furthermore, the making and 
approval procedures of urban plans including the public consultation procedures are clearly stated in the Ordinance. Third, to promote high quality of urban environment, urban design plans as the individual documents to deliver better urban environment are considered in the Ordinance. Apart from the Ordinance, the Shenzhen Municipal Government produced the Shenzhen Urban Planning Norm and Architecture and URBAN DESIGN Standard as technical guidance to direct the plan-making and the planning management. Both of these use a coding method, tailoring the national requirements to local situations, which also makes it easy to apply to the day-to-day decision-making. Fourth, the issues of formal planning-application process, monitoring and planning appeal are all included. Apart from the requirements from the Ordinance and the Norm, urban design is also promoted and regulated by the Planning Bureau's Administration Handbook. This Handbook defines the functions and the responsibilities of the Planning Bureau and its departments. It also guides the operations of all the administration activities within the Planning Bureau.

The design and development of Shenzhen Futian CBD reveals a Chinese city learning to practise urban design on a broad scale. In the 1980s, the original city centre was in Luohu District, located just next to the Shenzhen/Hong Kong Customs checkpoint. As the city's industrial sector continuously grew, a new demand for industrial services emerged. Together with the Municipality's strategy to promote real estate development, and to establish a new urban image to attract more inward investment, Futian CBD was designated in early 1986 with high environmental quality expectation (Figure 2). The broad layout and street system of the CBD was decided before 1994 by a few conceptual masterplans and transport studies. From 1996, a few international consultations in different scales started to shape the new CBD into the current built form (Chen, 2002). In 1996, the international consultation provided urban design ideas for the Core Area, with the result of designating the transport system, subway lines and the form of City Hall; in 1997, Kiso Kulokawa Architects (Japan) designed the Central Axis public space system; a detailed URBAN DESIGN Guideline to a small urban block was produced by Skidmore Owings \& Merrill LLP (USA) in 1998 and was fully implemented in later years with a strong influence on the later design-control practice; in 1999, international consultation for urban design, traffic and underground space for the whole CBD was carried out; in 2000, the site for Shenzhen Conference and Exhibition Centre was chosen in the south end of the CBD; and in 2002 more detailed studies were carried out to improve the central squares and the pedestrian system, and the Statutory Map was updated (Chen, 2002). Apart from these, all the projects within the new CBD have been subject to design competition, including architecture design and landscape design. The strong political support from the city mayor has been driving the CBD project to a modern service district. It is worth mentioning here that the 20-year CBD development in Shenzhen reveals a progressive learning experience on urban design control, from the perspective of the socialist aesthetic of grand square, architecture and boulevard at the early stage, to the later elevational control, and eventually using detailed urban design studies and using the land power to address the quality of the public realm.

\section{The Case of China Phoenix Building}

This case study reveals the most important aspects of China's design control. It illustrates the importance of the external skill support to development control, and shows that the capability of planning control can be increased when land management authority ${ }^{3}$ provides relevant support. It also shows how the traditional rigid zoning mechanism can be improved by preplanning negotiation, and how frequently revising the statutory plans under a certain procedure can improve its flexibility. It also signals design control moving from elevational control to address the quality of public realm. A site with a size of $22000 \mathrm{~m}^{2}$ is located in the east end of the Futian CBD, next door to the New City Hall, facing south on the busiest arterial road Shennan Boulevard. Located outside the original core area of the CBD, the site was not included in the 1996 CBD URBAN DESIGN International Consultation, and thus lacked clear guidance on the building form (Figure 2).

The local politicians were aware of the positive impacts of housing the internationally known Chinese TV broadcasting company on the city. ${ }^{4}$ To help the company to strengthen its image, in June 2001 the government signed the Land Contract with Phoenix TV, allowing it to build up to $48700 \mathrm{~m}^{2}$ with Floor Area Ratio (FAR) of 


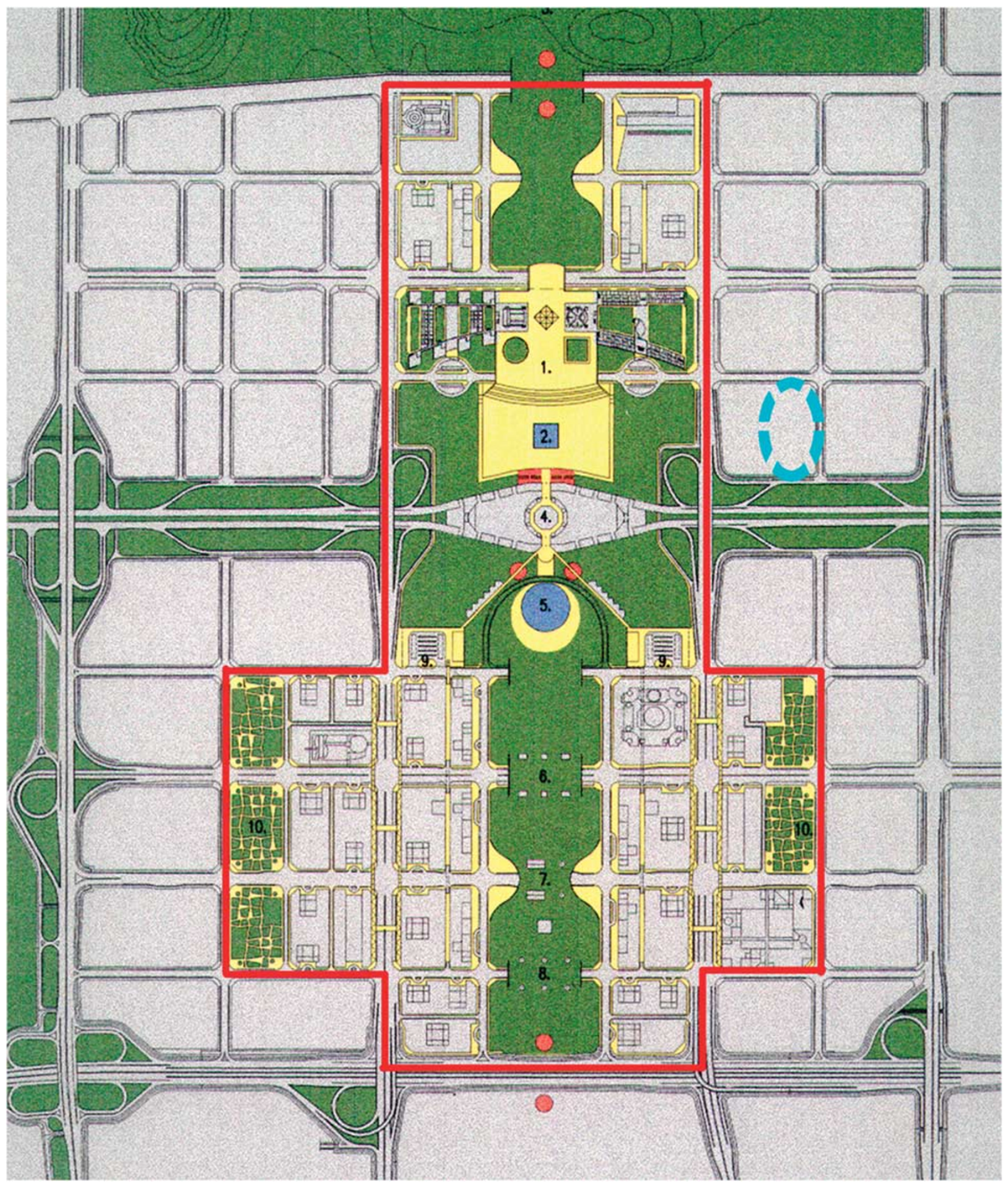

Figure 2: 1996 Shenzhen CBD urban design boundary and the site location.

Source: Chen (2002). This masterplan was developed by John M.Y. Lee/Michael Timchula Architects, who designed the City Hall, Central Axis and the system.

2.2 and $90 \mathrm{~m}$ building height, but no floor space was allowed to be used commercially (Figure 3). The Land Contract always contains certain conditions such as the building setback, locations for tower and square, green ratio and the requirement for a design competition. Here, it additionally requires the introduction of a broadcasting square open to the public either on the ground 


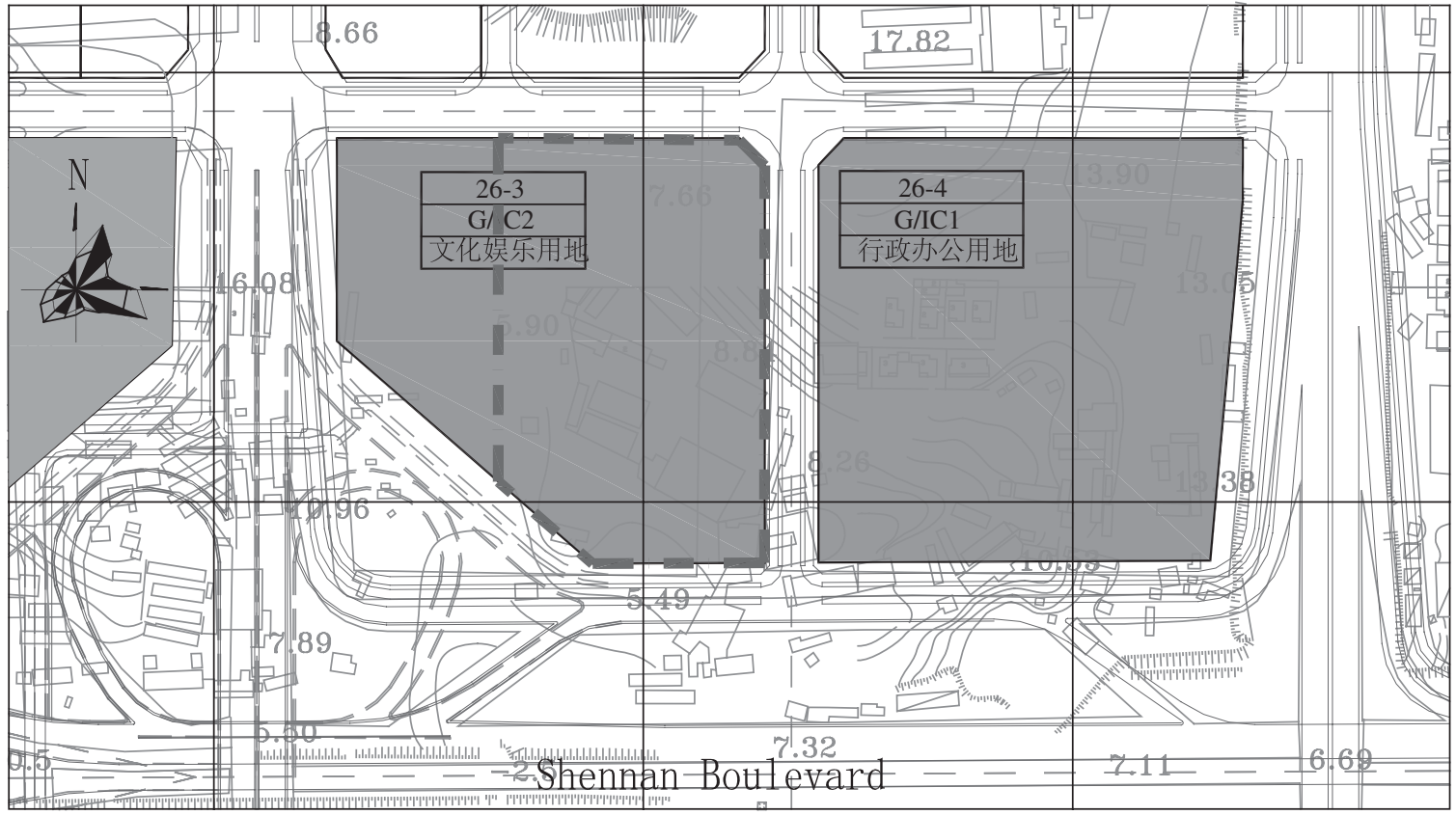

Figure 3: The site in CBD Statutory Map 1998. The site is bounded by Shennan Boulevard to its south and two access roads to its east and north. The Statutory Map permitted FAR for site of 2.2, plot size of $22000 \mathrm{~m}^{2}$, land use as cultural and entertainment.

floor or in the square, as the potential contribution to the public. To pay for the development costs, Phoenix TV was willing to change the Land Contract to allow additional commercial space to be developed. In the pre-planning discussion, in September 2001, Phoenix TV tried to increase the total floor space to $80000 \mathrm{~m}^{2}$. The Planning Bureau was willing to consent to the new requirement, but needed to wait for a formal amendment to the Statutory Map. ${ }^{4}$

In 2001, the German design consultant Obermeyer Planen + Beraten produced a comprehensive masterplan for the whole CBD, with a more detailed sub-division of every urban block (Figure 4). The masterplan also indicates the preferred form of the development on the Phoenix TV site. The new masterplan provided a chance to amend the Statutory Map, which could also legitimate the proposed consent from the Planning Bureau.

With more development proposed on the adjacent sites, in March 2002 the Planning Bureau commissioned the Shenzhen Urban Planning and Design Institute (SUPDI) to carry out an urban design study on this quarter. The principles and the parameters from the study have been the baseline for the government to negotiate with the developer on land release and planning control.
In line with the Obermeyer masterplan, and with regard to the requirements brought forward by the developer and liaising with the Planning Bureau, SUPDI prepared a detailed masterplan to achieve an ordered and permeable urban form. In this detailed masterplan, a chessboard street structure is defined with smaller blocks, street walls are regulated, open spaces are provided and enclosed, and the vehicle circulation is streamlined. But there was no effort made to improve the severance produced by the surrounding highways, or to better integrate the gated residential development to its north (Figure 5). The confirmation from the developer that he would comply with the new design parameters enabled the Planning Bureau to implement this urban design plan. As a result, this study reduced the plot size for Phoenix TV, but allowed it to build the floor space up to $80000 \mathrm{~m}^{2}$. The government negotiated with the developer and eventually reclaimed the rest of the site. To legitimate the above urban design study, the CBD Statutory Map was amended following a formal procedure in the Statutory Map Committee according to the study. The urban design study then provided the detailed conditions for new developments.

Two supplements for the Land Contract were signed in November and December of 2002 


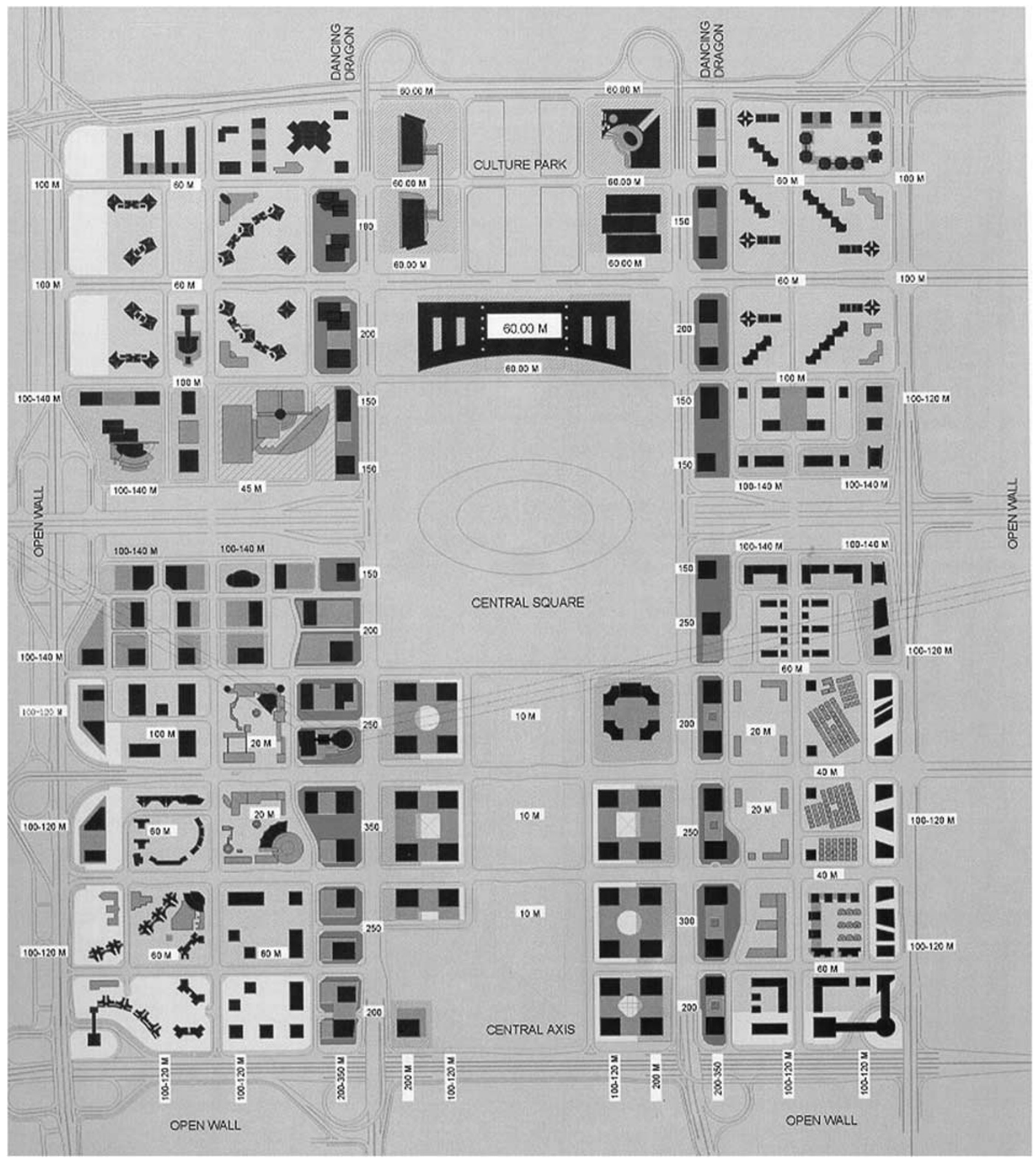

Figure 4: Obermeyer's masterplan 2001 (Chen, 2002). The masterplan was claimed to reflect the traditional Chinese city character. The key principles were to introduce two rows of high-rise buildings along the South-North axis and a row of high-rise buildings along the East-West axis. It strengthens the design concept of nine-compartment. North-South high street walls with defined waves ('Dancing Dragons') are located along the central axis. Residences are sitting in the four corners. Along the two central axes, governmental and cultural district sit in the north, and commercial and office district sit in the south.

according to the new Statutory Map. In these two supplements, the government regained the plot to the north of the Phoenix TV site of $11600 \mathrm{~m}^{2}$, and Phoenix TV site shrank from 22000 to $11000 \mathrm{~m}^{2}$.
In return, Phoenix TV was allowed to increase the total floor space up to $80000 \mathrm{~m}^{2}$, with $35000 \mathrm{~m}^{2}$ of office space $\left(20000 \mathrm{~m}^{2}\right.$ self-use), $30000 \mathrm{~m}^{2}$ of $\mathrm{SOHO}$ (small office home office) space $\left(5000 \mathrm{~m}^{2}\right.$ 


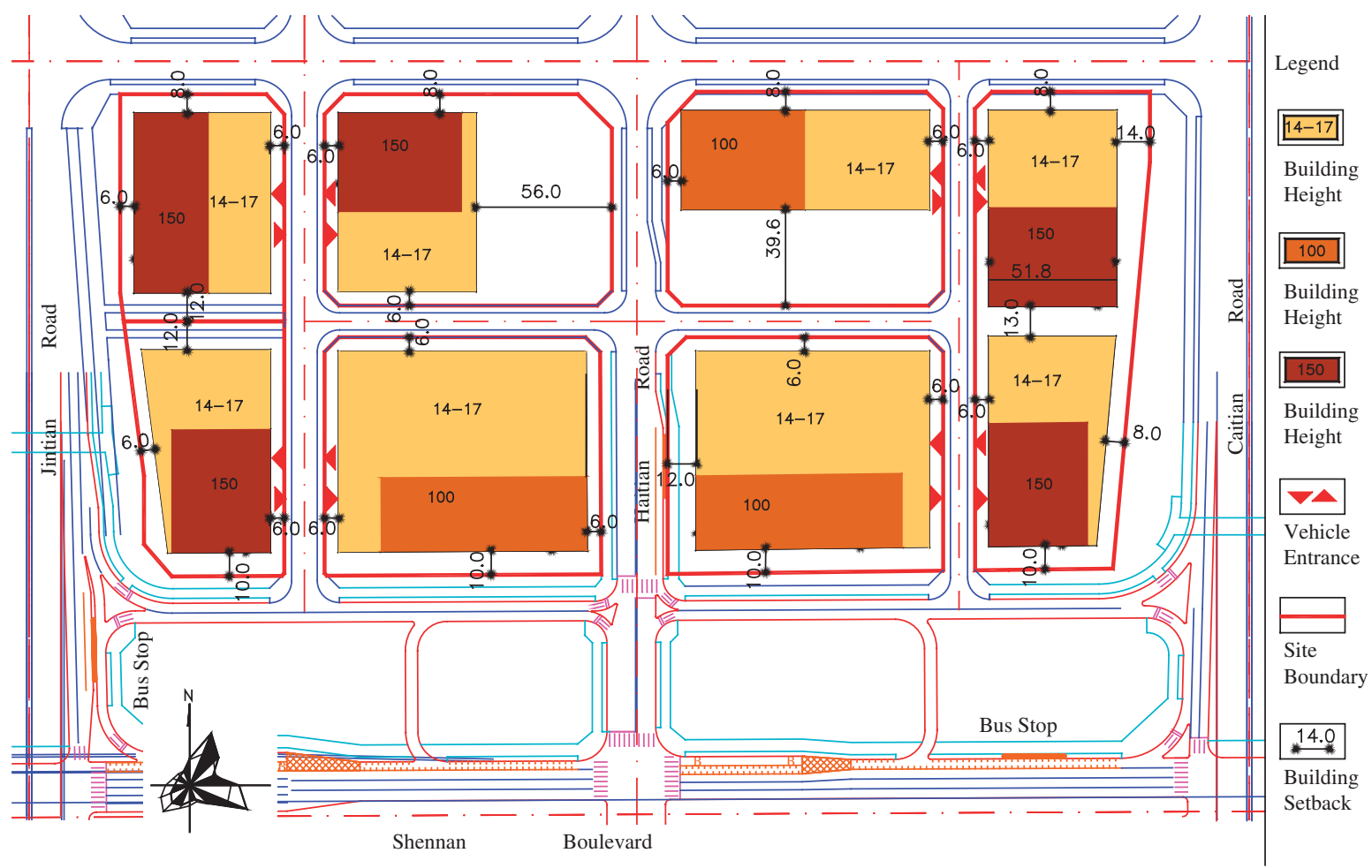

Figure 5: Urban Design Study for Block 26 (SUPDI, 2002), adapted by the researcher. The study sub-divides the two large blocks into seven smaller plots containing some eight individual buildings. It decides the building heights and locations, generates two squares in the block and regulates the vehicle entrances.

self-use) and $15000 \mathrm{~m}^{2}$ of commercial space $\left(6300 \mathrm{~m}^{2}\right.$ self-use) without paying extra fees to the government. In December 2002, the Land Use Planning Permit was issued according to the parameters in the Land Contract, and a regulated FAR of 7.25, building coverage of 70-80 per cent and building height of $110 \mathrm{~m}$.

In March 2004, a design competition was held using the conditions issued, and the entry from United Design Studies (UDS) (Canada) won. The reason UDS won was because it complied with the design conditions and offered rational internal layouts that met the developer's requirements. ${ }^{4}$ The site was proposed to be occupied by three buildings of SOHO, office and Phoenix Service, each with a maximum height of $100 \mathrm{~m}$. A semipublic space was created between the three buildings, with entrances from the major directions and surrounded mainly by commercial uses. $\mathrm{SOHO}$ was located to the east of the site, mixed with commercial uses on the lower levels. The Phoenix TV Service building is located to the north of the site, with visitor viewing corridors open to the public in its Western facade. The office tower to the south has separate entrances for the commercial office and the Phoenix office. Two arcades were introduced into the podiums to the north and the east (Figures 6 and 7).

In April 2004, the developer submitted the scheme from UDS for Design Project approval. With some minor amendments on the floor plans, the project was finally granted a Construction Planning Permit in September 2005.

By the time of this research, the construction was nearly completed. The site was developed in accordance with the permitted drawings, arcades were built to address the streets and the public space between the three buildings was provided. A pedestrian-friendly environment was introduced by the development, with shop fronts, arcades and building entrances fronting the street. The facade at street level was reduced to a height of two floors, providing a human scale and continuous street walls. More importantly for this scheme, a staircase was constructed leading to the broadcasting halls for viewing purposes for general visitors (Figure 8); however, its form is questionable. A more legible form and climate 


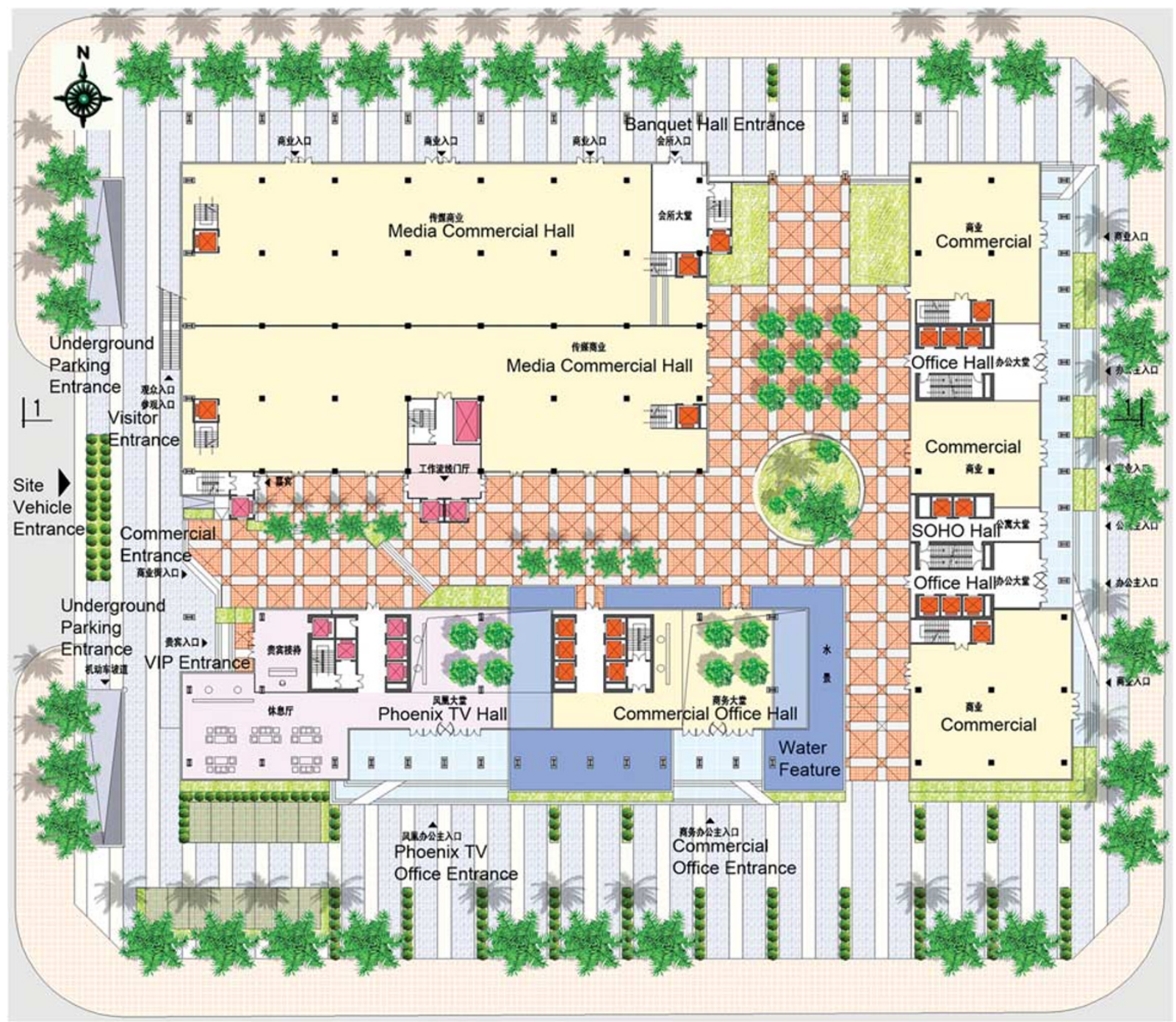

Figure 6: Ground floor plan of the winning scheme, by UDS Architects.

protection facilities are needed for easier use by the public. Overall, the development provides a positive impact on the street, and adds value for the public by introducing a semi-public square and opening up its broadcasting halls for visitors. However, the site is still poorly accessible from the south because of the Shennan Boulevard. The urban arterial road isolates the southern part of the CBD from the north, given its $200 \mathrm{~m}$-wide highway structure (distance measured from the site boundaries along the road). It results in an uncomfortable and dangerous pedestrian crossing experience, and further cuts the possible interaction between the south and the north. The postconstruction treatment is still to be investigated after the landscaping and the introduction of the property maintenance.

\section{Discussion}

This case is a successful attempt at design control. It adds value to the public and provides a harmonised urban environment. The process illustrates a number of key issues in design control, when compared to international good practice. First, design innovation flourished in the planning process. The semi-public space introduced by UDS was neither required by the planning authority nor mentioned by the previous urban design study. The idea of 'opening up the building to the public' was generated by the project architects from their understanding of the client's requirement and the functional performance of the building. Because of its potential contribution to the public realm, it was supported 

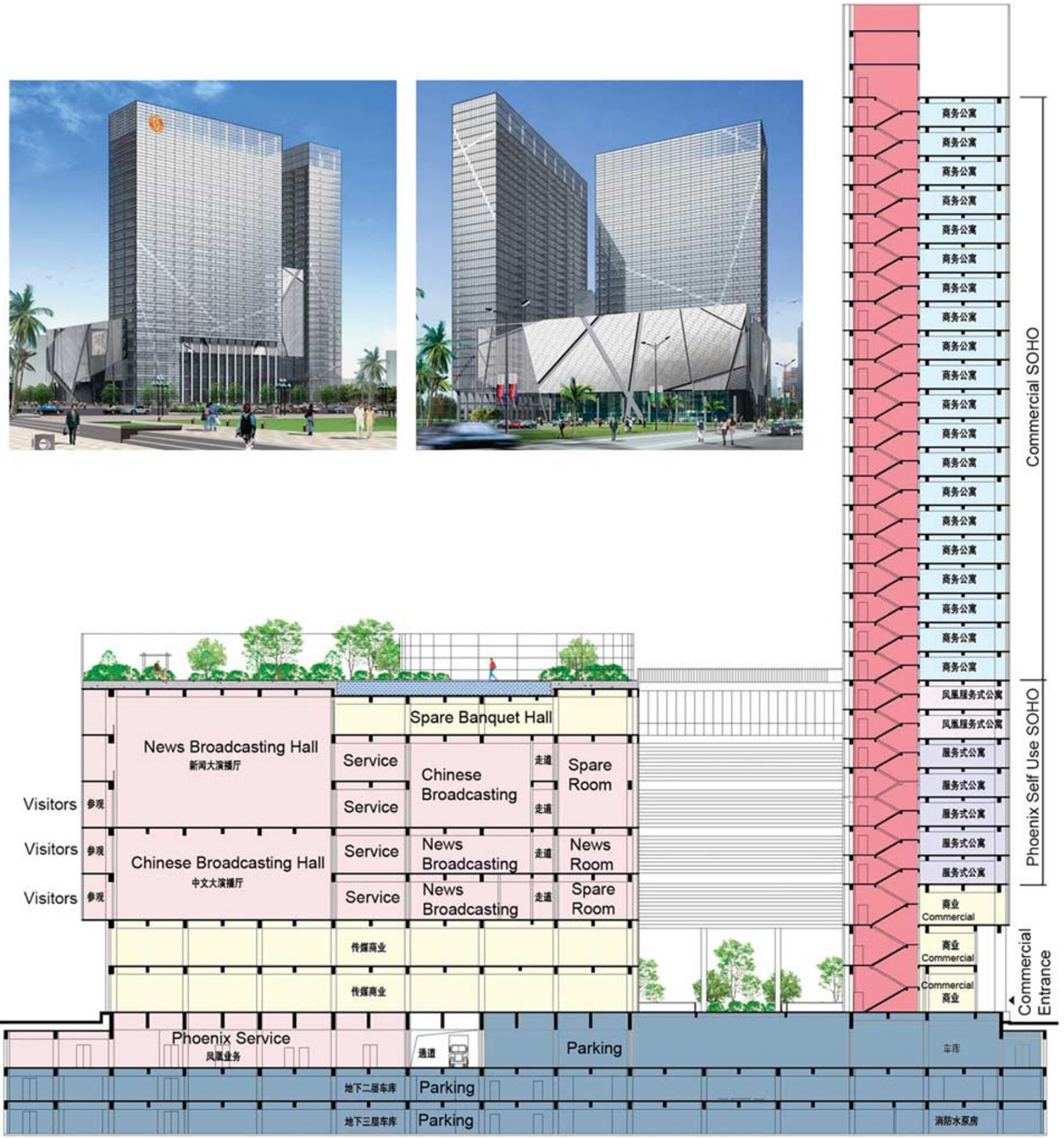

Figure 7: Scheme section and the artist impressions, by UDS Architects.

by the jury and the planning authority. Design innovation within the given design conditions in this case contribute significantly to amenities for the general public. Second, additional skill input is crucial for the planning authority to be able to deal with planning applications under the pressure for a speedy decision, which is also in line with some Anglo-American good practice. They commissioned the local planning institute liaised with different interest parties to generate an acceptable and practical solution for development control. The urban design study enables the planning officers to explore a deeper understanding of the site, the development capacity, the possible built form and the land uses, and provides detailed guidance for planning negotiation. Its non-statutory status at the same time allows more flexibility and provides confidence 

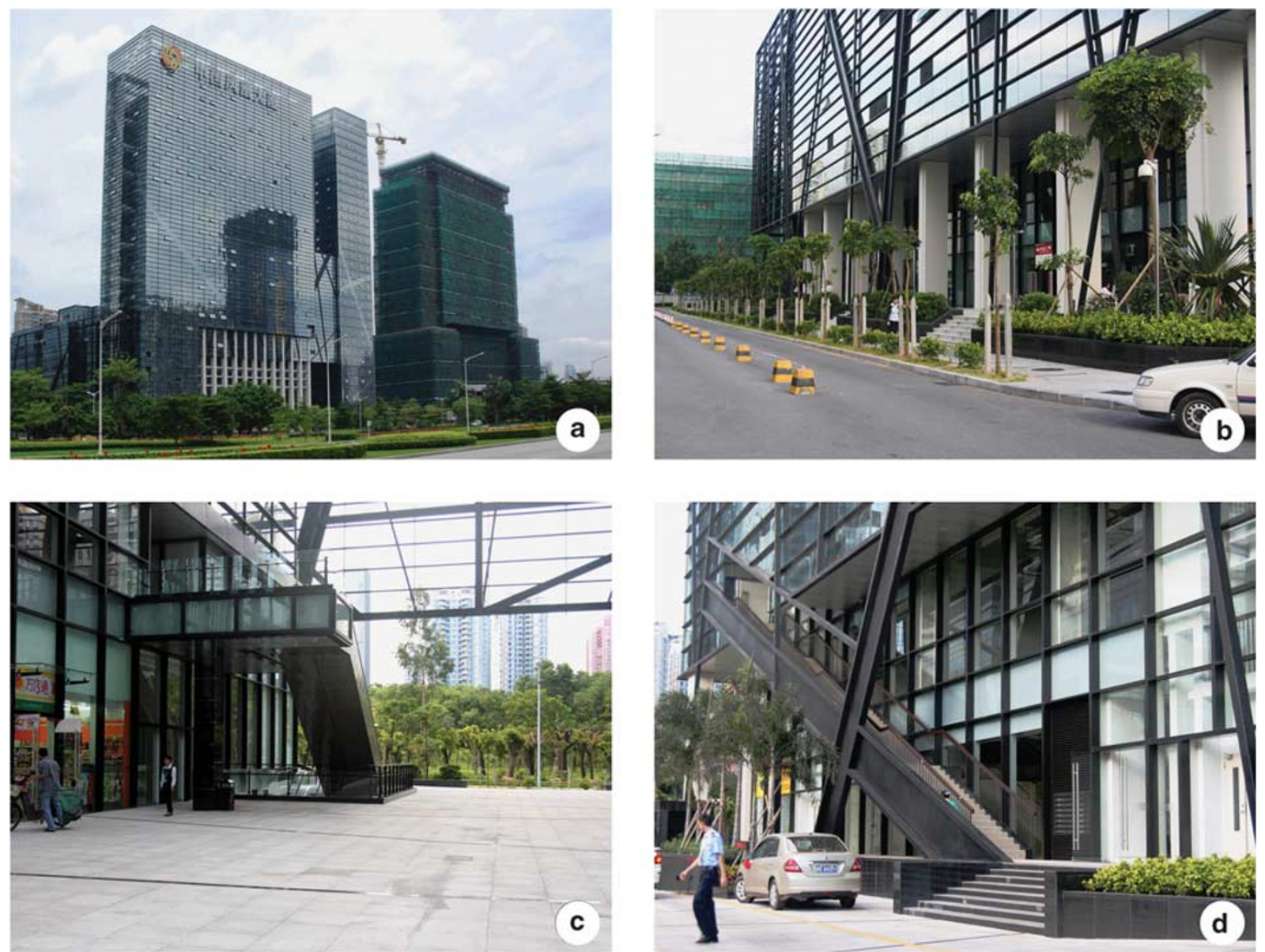

Figure 8: Phoenix TV Building onsite. (a) Phoenix TV Building with the China Customs House. A unified street wall is achieved by the two projects. But the highway isolates the site from the south. (b) Two-floor high pedestrian arcade in the northern facade. Shop front and plants give the place a sense of life. (c) The semi-public square within the building is surrounded by a few retail units, providing a sense of vitality to the project. (d) Staircase leading to the broadcasting halls to the west.

for the planning officers to propose amending the Statutory Map. Given the time and skill constraints, the Shenzhen planning authority contracts out the small studies, and eventually gains a more effective planning control. Third, China's unique land policy provides good opportunity for public design intervention, if cooperation exists. Working in line with the land resource authority enhances the ability of the planning authority to develop a more effective design control. Generally, there is limited inter-department cooperation in China (Wu et al, 2007), but this case study provides a more positive picture. In this project, without the land resource authority's support to negotiate with the developer to reclaim a part of the site, the planning authority's desire to increase the development density and environmental quality would be far more difficult to achieve. Given the fact that this success was achieved when planning function and land management function were under control in the same bureau, the continuity of this kind of smooth cooperation is still to be examined. Fourth, this case also signals that the emphasis of planning control starts to move from the purely elevational control towards addressing the quality of the public realm, with the application of some major generic urban design principles. Pedestrian arcades and active and enclosed street frontages were all stressed in the planning control process. The zoning-like rigid Statutory Map originally only controlled the building envelopes and the density, and this is now compensated by the negotiation and design conditions.

Fifth, the newly introduced Statutory Map system, which provides a statutory power similar 


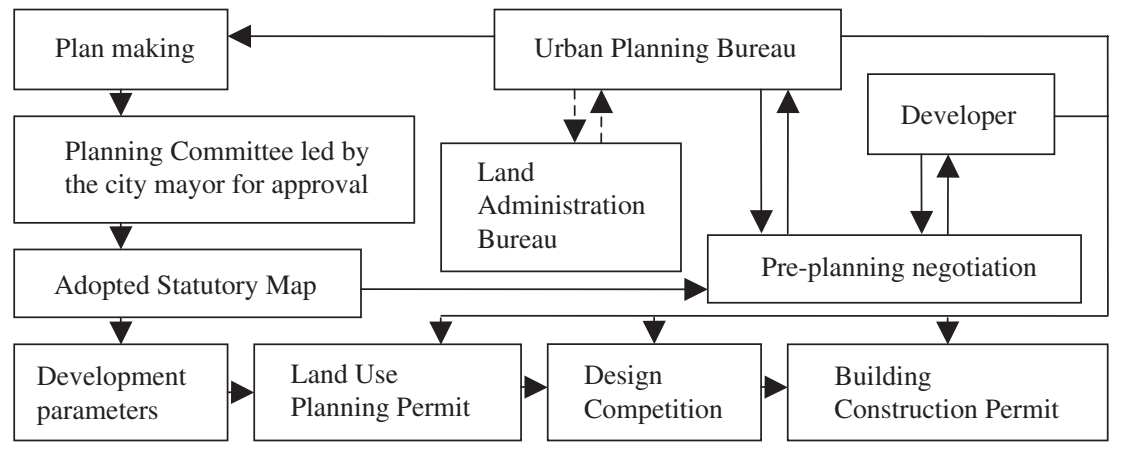

Figure 9: Pre-planning negotiation model.

to the traditional zoning-like detailed controlled plan, increases the transparency of the decisionmaking process and the accountability of government agents. The amendment of the Statutory Map is no longer as easy as the change of the Detailed Plan, because a formal consultation and approval procedure should be followed, and this is carried out by the Planning Committee instead of the Planning Bureau. In China's speedy urbanization environment, the Statutory Map soon reaches its limit. But the frequent amendments of Statutory Maps according to an administrative rule can help the government to achieve flexible control with a degree of certainty. However, the increase in the frequency of Statutory Map amendments would encourage the developer to disrespect the Statutory Map and to always seek to break the development limit. The lack of staff resources in the Planning Committee would also result in easy consent for any proposed amendment due to the heavy workload. The degree of accountability would therefore be reduced. Lastly, this case reveals a new process of development control in China (Figure 9). When a Statutory Map made by a planning institute goes through the Planning Committee and public consultation, it is adopted. The parameters for every piece of land then become the basis for preplanning negotiation between the developer and the Planning Bureau. If the development proposal involves any change in any parameter, the city mayor and the Land Administration Bureau are likely to be consulted, and the developer or the Planning Bureau should also provide sufficient evidence to support the change. The Planning Bureau then submits the new parameter to the Planning Committee to amend the Statutory Map, which needs to follow the same procedure as adopting a new one. When the parameter is changed, the 'Two Permits and One Permission
Note' planning application follows. This new process brings negotiations into the pre-planning stage. The major conflicts between the private developer and the public interest are to be solved outside the formal planning application process, partly speeding up the decision-making process. More importantly, the result of the negotiation is monitored by another body - the Planning Committee and the general public. The accountability therefore can be increased.

But there are some challenges in this process. The over-generous highway standard remains a major problem in this project. This cannot be solved by the individual control of the development project. It can only be solved at the strategic level, which would need to change the city's or district's transport system and the public transport provision. This case has not touched on the planning appeal and public participation issues. During the whole development control process, there was no public consultation. The residents to the north of the site were not consulted and were not even informed about the planning application until the project was onsite. Sustainability was not mentioned in any part of the design-control process. The features such as energy performance of the building, natural ventilation and natural lighting were not required by the planning authority.

\section{Conclusion}

Shenzhen's experience in design control at a large degree is in line with international good practice, with effective cooperation between planning and land resource authorities, and with its emerging discretionary zoning practice. This research reveals a practical trend in Shenzhen's urban design practice, which is taking the liveable and responsive environment as the ideal form, and is 
also adopting a more transparent and fair review process. While most Chinese cities are suffering from rapid urban development, giving high priority to economic development and building modern urban images, they are sacrificing the real quality of the built environment. But Shenzhen's planners are slowly finding a way to challenge the power of the elite-developer coalition, and are seeking opportunities to improve the quality of the public realm. Their urban design practice is slowly moving from image building towards a more substantive environmental quality control. Shenzhen's pioneering position in China's designcontrol practice benefits from the local legislation, the relatively transparent decision-making environment (administrative rules), the political support and the correct understanding of the city function. Globalization came to China at the early stage of China's market reform, which has led to an unprecedented speed of economic development, social change and environmental alteration. The Anglo-American experiences show that a country needs to keep adopting and sharpening its planning tools to better shape its built environment. Therefore, the ideology to manage these changes is most needed in academic research. Nevertheless, an ideal design-control system that acts as the watchdog for the general public is still not in place, not least because of the background of partial reform and pro-growth urban development strategy.

\section{Notes}

1 Confucian ideology, conceived in the Chunqiu period of China by Master Kongzi, flourished during the Han Dynasty, and has been influencing Chinese thinking until now. It provides a rigid hierarchy of emperor-first and malefirst social order, broadly accepted and promoted by Chinese kings and emperors.

2 Tao promotes the accord of heaven and man (tianren heyi), and contributes to the development of geomantic principles (fengshui).

3 Shenzhen's urban planning and land resources management functions were within the same bureau during the time when this project processed its application. In 2004, these two functions were divided and managed by two individual bureaus.

4 Interview with the planning officer by the author.

\section{References}

Barnett, J. (1974) URBAN DESIGN as Public Policy: Practical Methods for Improving Cities. New York: Architectural Record.
Bentley, I., Alcock, A., Murrain, P., McGlynn, S. and Smith, G. (1985) Responsive Environments. Oxford, UK: Architectural Press.

Biddulph, M. (1999) Urban design strategies in practice: An introduction. Built Environment 25(4): 281-288.

Blaesser, B.W. (1994) The abuse of discretionary power. In: B.C. Scheer and W.F.E. Preiser (eds.) Design Review: Challenging Urban Aesthetic Control. New York: Chapman \& Hall, pp. $42-50$.

Chen, Y. (ed.) (2002) URBAN DESIGN International Consultation for Core Area of Shenzhen Futian CBD. Beijing, People's Republic of China: China Architecture \& Building Press, (in Chinese).

Cullen, G. (1961) Concise Townscape. Oxford, UK: Architectural Press.

Cullingworth, B. and Nadin, V. (2006) Town and Country Planning in the UK, 14th edn. London: Routledge.

Cullingworth, B. and Roger, W.C. (2003) Planning in the USA: Policies, Issues and Processes, 2nd edn. London and New York: Routledge, p. 354.

DCLG. (2006) Design Coding in Practice: An Evaluation. London: Department for Communities and Local Government.

DETR and CABE. (2000) By Design: URBAN DESIGN in the Planning System: Towards Better Practice. London: Thomas Telford.

DfT and DfCLG and WAG. (2007) Manual for Streets. London: Thomas Telford.

Esherick, J.W. (ed.) (2000) Remaking the Chinese City: Modernity and National Identity, 1900-1950. Honolulu, HI: University of Hawaii Press.

$\mathrm{Fu}, \mathrm{Z}$. (2002) The state, capital, and urban restructuring in postreform Shanghai. In: J.R. Logan (ed.) The New Chinese City: Globalization, and Market Reform. Oxford, UK: Blackwell Publishers, pp. 106-120.

Jacobs, J. (1961) The Death and Life of Great American Cities. New York: Vintage.

Katz, P. (1994) The New Urbanism: Towards an Architecture of Community. New York: McGraw-Hill.

Lai, R.T.-y. (1988) Law in URBAN DESIGN and Planning: The Invisible Web. New York: Van Nostrand Reinhold, p. 470.

Lai, R.T.-y. (1994) Can the process of architectural design review withstand legal scrutiny? In: B.C. Scheer and W.F.E. Preiser (eds.) Design Review: Challenging Urban Aesthetic Control. New York: Chapman \& Hall, pp. 31-41.

Larice, M. and Macdonald, E. (2007) Editor's introduction to 'Conclusion: Great streets and city planning'. In: M. Larice and E. Macdonald (eds.) The URBAN DESIGN Reader. London: Routledge, p. 387.

Logan, J.R. (2002) Three challenges for the Chinese city: Globalization, migration, and market reform. In: J.R. Logan (ed.) The New Chinese City: Globalization, and Market Reform. Oxford, UK: Blackwell Publishers, pp. 3-21.

Loukaitou-Sideris, A. and Banerjee, T. (1998) URBAN DESIGN Downtown: Poetics and Politics of Form. Los Angeles, CA: University of California Press.

Lu, D. (2006) Remaking Chinese Urban Form: Modernity, Scarcity and Space, 1949-200. London: Routledge.

Lynch, K. (1960) The Image of the City. Cambridge, MA: The MIT Press.

Nelissen, N. (1999) Preliminary conclusions: Ten megatrends in aesthetic control in Europe. URBAN DESIGN International 4(1\&2): 77-78.

Punter, J. (1987) A history of aesthetic control: Part 2, 19531985. Town Planning Review 58(1): 29-62. 
Punter, J. (1999a) Improving the instruments, processes and products of aesthetic control in Europe. URBAN DESIGN International 4(1\&2): 79-99.

Punter, J. (1999b) Design Guidelines in American Cities: A Review of Design Policies and Guidance in Five West-Coast Cities. Liverpool, UK: University of Liverpool Press.

Punter, J. (1999c) Design. In: B. Cullingworth (ed.) British Planning: 50 Years of Urban and Regional Policy. London: The Athlone Press, pp. 137-155.

Punter, J. (2003) The Vancouver Achievement: Urban Planning and Design. Vancouver, BC: UBC Press.

Punter, J. (2007) Developing urban design as public policy: Best practice principles for design review and development management. Journal of URBAN DESIGN 12(2): 167-202.

Schaller, C. (1999) Aesthetic control management in the German planning process. URBAN DESIGN International 4(1\&2): 39-45.

Scheer, B.C. and Preiser, W.F.E. (eds.) (1994) Design Review: Challenging Urban Aesthetic Control.. New York: Chapman \& Hall.

Sheer, B.C. and Preiser, W.F.E. (1994) Design Review: Challenging Urban Aesthetic Control. New York: Chapman \& Hall.

Southworth, M. (1989) Theory and practice of contemporary urban design: A review of urban design plans in the United States. Town Planning Review 60(4): 369-402.

Standing Committee for the People's Congress P. R. C. (1989) City Planning Act. Beijing, People's Republic of China: Standing Committee for the People's Congress P. R. C, (in Chinese).
SUPDI. (2002) URBAN DESIGN Study for Block 26. Futian Central Business District Shenzhen: SUPDI, (in Chinese).

UTF. (1999) Towards an Urban Renaissance: Final Report of the Urban Task Force Chaired by Lord Rogers of Riverside. London: E\&FN Spon.

Whitehand, J.W.R. and Gu, K. (2006) Research on Chinese urban form: Retrospect and prospect. Progress in Human Geography 30(3): 337-355.

Wright, G. (1999) Urban design 12 years on: The Birmingham experience. Built Environment 25(4): 289-299.

$\mathrm{Wu}, \mathrm{F}$. (2000) The global and local dimensions of place-making: Remaking Shanghai as a World City. Urban Studies 37(8): 1337-1359.

$\mathrm{Wu}, \mathrm{F} ., \mathrm{Xu}, \mathrm{J}$. and Yeh, A.G.-O. (2007) Urban Development in PostReform China: State, Market and Space. London: Routledge.

Xie, Y. and Costa, F.J. (1991) Urban design practice in socialist China. Third World Planning Review 13(3): 277-296.

Yin, R.K. (2003) Applications of Case Study Research, 2nd edn. Thousand Oaks, CA: Sage Publications.

Yu, L. (2004) The Performance of the Urban Macro Plan in China in the Transition to a Market Economy. PhD Dissertation, Cardiff University.

Zhang, T. (2002) Challenges facing Chinese planners in transitional China. Journal of Planning Education and Research 22: $64-76$

Zhu, J. (1999) The formation of a market-oriented local property development industry in transitional China: A Shenzhen case study. Environment and Planning A 31(10): 1839-1856. 